\title{
Invited authors \\ "Living well but looking good: A modern health dichotomy" A brief overview on women's body image
}

\author{
Idalina Shiraishi Kakeshita \\ Maria Fernanda Laus \\ Sebastião Sousa Almeida \\ University of São Paulo, Brazil
}

\begin{abstract}
Living well but looking good. This health dichotomy is among the majors concerns in modern Western societies, especially for women. But what is "living well"? And what does it mean to "look good"? Are these concepts exclusionary or are they related in females' minds? In this paper, we sought to discuss such approaches by defining these terms, highlighting the current role of women within our society, and the importance of the body to Brazilian women. Moreover, the possible consequences on health of having a negative perception of the own body are raised, including its relation to physical activity.
\end{abstract}

Keywords: body image, health, women

Resumo- “A saúde da mulher: Viver bem ou parecer bonita. Um breve panorama sobre a imagem corporal das mulheres." Motivos para a prática de exercício físico em uma amostra de universitários brasileiros." Viver bem, mas parecendo bem. Essa dicotomia da saúde está entre as maiores preocupações em sociedades ocidentais modernas, especialmente para as mulheres. Mas o que é "viver bem"? E qual o significado de "parecer bem"? São esses conceitos excludentes ou eles estão relacionados na mente das mulheres? Neste artigo, buscamos discutir estas abordagens, definindo tais termos, ressaltando o atual papel da mulher em nossa sociedade e a importância que o corpo assume para as brasileiras. Além disso, as possíveis consequências na saúde de uma imagem corporal negativa também são levantadas, incluindo sua relação com a atividade física.

Palavras-chaves: imagem corporal, saúde, mulher

Resumen - "Vivir bien, pero con buena apariencia: Una dicotomía de la salud moderna. Una breve descripción de la imagen corporal de las mujeres." Vivir bien, pero con buena apariencia. Esta dicotomía de la salud es una de las principales preocupaciones en las sociedades occidentales modernas, en especial para las mujeres. Pero lo que es "vivir bie"? Y cuál es el significado de "verse bien"? Estos conceptos son mutuamente excluyentes o están relacionados en las mentes de las mujeres? En este artículo se analizan estos planteamientos, la definición de tales términos, destacando el papel actual de la mujer en nuestra sociedad y la importancia de que el cuerpo necesita para el brasileño. Por otra parte, las posibles consecuencias de salud de una imagen negativa de su cuerpo también se plantean, incluida su relación con la actividad física.

Palabras claves: imagen corporal, salud, mujeres

\section{Living well but looking good}

Living well and looking good as health related expressions have firstly to be considered as health concepts. According to World Health Organization (WHO, 2009, p.1) "health is a state of complete physical, mental and social well-being... seen as a resource for everyday life, not the objective of living... a positive concept emphasizing social and personal resources, as well as physical capacities." "Good health is a major resource for social, economic and personal development and an important dimension of quality of life... Political, economic, social, cultural, environmental, behavioral and biological factors can all favor health or be harmful to it" (World Health Organization [WHO], 2009, p. 2).

The United Nations Millenium Declaration, MDG 3, explicitly recognizes that "the equal rights and opportunities of women and men must be assured," and that "...empowerment of women, including ensuring access to health information and control of resources such as money, is important for achieving gender equality and health equity... However, the ratio of female-to-male earned income is well below parity in all countries for which data are available" (WHO, 2003, p. 1, 2).

Thus, it has been recognized the importance of women living well because of their role in contemporary society. But what is the meaning of living well? And what is the meaning of looking good for women or in feminist perspectives?

Regarding to "living well," it is already well recognized, even by government all around the world, that a physical and mental health implies physical activity and healthy eating 
(U.S. Department of Health and Human Services - HHS, 2013). The World Health Organization has already published the Global strategy on diet, physical activity and health (Brasil - Ministério da Saúde, 2004) where they present scientific evidences related to the objectives, goals and recommendations about preventing obesity epidemic and chronic diseases such as some cardiovascular diseases and diabetes. The most important thing is that the problems mentioned are the most common and expensive of all health problems, but they are also the most preventable basically responsible for some changes in lifestyle.

And what does it mean to "look good," to be healthy and beautiful? What is beauty? What is attractiveness?

\section{Body image: a brief overview focusing on women's body}

According to Paul Schilder (1950, 1999) body image is the picture of our own body which we form in our mind, the way in which the body appears to ourselves. This construct was expanded and Slade (1988, as cited in Gardner, 1996, p. 327) defined body image as "the picture we have in our minds of the size, shape and form of our bodies; and to our feelings concerning these characteristics and our constituent body parts (p. 20)." Gardner (1996) considered this definition and stated that "the mental picture that we have of our bodies thus reflects a perceptual component and the feelings about our body correspond to an attitudinal component (p. 327)." More recently, Cash and Smolak (2011) edited the second edition of Body Image - A Handbook of Science, Practice, and Prevention; and Cash (2012) organized the Encyclopedia of Body Image and Human Appearance. In the first book, the authors offer a historical and conceptual context, highlighting important milestones in body image research and knowledge. In the second one, Cash (2012) brought together the most important researchers in the field to spread out the knowledge about body image nowadays, considering the construct complexity. Then, body image construct is currently recognized on a comprehensive approach as "how people experience their own embodiment, especially, but not exclusively, their physical appearance characteristics, including their physical functional competencies and biological integrity" (Cash, 2012, vol. I, p. 793).

Concerning females' body image in Western cultures, women should be slim, thin, with firm-looking body (muscle tone), like Barbie-doll physically impossible stereotype, in order to seem self-controlled, elegant and socially attractive and accepted (Grogan, 2008). Researches in the last two decades have demonstrated that body dissatisfaction was not confined to people diagnosed with eating disorders or some specific body image disorder, but affects the majority of people and is more prevalent within women (Laus, 2013).

Feminist theorists state that Western societies stress women as objects to be watched and evaluated, shape women's consciousness and make them dependent on others for approval. McKinley (2011) proposed an Objectified Body
Consciousness theory (OBC) that consists of body surveillance, internalization of cultural body standards, and appearance control beliefs. In addition, in the current culture of consume, billions of dollars are invested on ideal body beauty/looking good and, on the other hand, billions of dollars are spent with preventable diseases related to healthy living/living well.

Another theory proposed by Thompson, Heinberg, Altabe, and Tantleff-Dunn (1999) to understand the factors that play a role in the development and maintenance of body image disturbance was the Tripartite Influence model. This model considers three primary sources of influence on body image disturbance and eating disorders: parents, peers and media, with two meditational links connecting influences to these dysfunctions: internalization of societal ideals of appearance and heightened appearance comparison tendencies. Several studies supported this sociocultural theoretical model (Van Den Berg, Thompson, ObremskiBrandon, \& Coovert, 2002).

Grogan $(2008$, p. 1, 2) has discussed about body image dissatisfaction and, by trying to understand it she added more knowledge to the field. She referred to the term proposed by Bryan Turner in 1992 of "somatic society" to describe the importance of the body in contemporary sociology, the high level of interest in the role of the body in social theory work, the increasing popular interest in body image concerns. She also referred to cosmetic surgery, reducing diets, strict diets (the dangers of dieting), driving to muscularity, and the increasing academic interest in all body image components and their assessment, particularly by psychology and sociology researchers.

This way, it is important to consider the social and historical construction of the idealized female body, because body concept, beauty and body image have not always been understood in the same way. Previously, women and girls were actively discouraged from expressions of vanity, but they had to concern their appearance in terms of tidiness and propriety. From last century till nowadays, female identity and role have been shaped according to the industrialization of societies, the rise of the media and the women exposure to it, high technology and consumption culture, as well as the changing of societal standards of attractiveness and beauty across cultures (Sentilles \& Callahan, 2012).

\section{Women's body image in sports/exercises}

Then, women athletic programs rises from the end of last century and their participation in sports become part of their social identity. The athletic girls were celebrated as beautiful bodies and appropriated in movement and there was the acknowledgement of a powerful female body shape (Sentilles $\&$ Callahan, 2012). Maybe it was the beginning of the trend on driving to muscularity also sought by women nowadays. It is well known that regular exercise is positive and a necessary daily activity to physical and mental health for everyone during all life stages. The benefits of exercises are 
well established on reducing risks for cardiovascular diseases, diabetes and certain cancers; on improving positive mood, lower levels of depression and anxiety (USHHS, 2013). However, in some groups or in some conditions research suggests that exercise may be associated with negative consequences and unhealthy behavior. Exercise related to high levels of body image dissatisfaction may increase the risk for disordered eating, muscle dysmorphia and female athlete triad (FAT), which is the co-occurrence of disordered eating, amenorrhea and osteoporosis. The disturbances above are associated with the exercise dependence and excessive exercise as common weight management behavior, likewise the indiscriminate consumption of steroids and dietary supplements (Petrie \& Greenleaf, 2012).

Among athletes, it is recognized the importance of studies about body image and eating disorders related to health and high performance in some sport's modalities, in which the attainment and maintenance of certain body pattern is required by demands of competitive environment (LePage \& Crowther, 2010). Thus, researches have been carried out with specific groups such as athletes of dance and aesthetic sports (Langdom, 2012), ballet dancers (Hass, Garcia, \& Bertoletti, 2012), rhythmic gymnastics athletes (Vieira, Amorim, Vieira, Amorim, \& Rocha, 2009) and other sports groups, in order to examine body image disturbance and eating behavior concerns, because some sports have a primary focus on the athlete's appearance with emphasis on leanness.

\section{Body image assessment}

The cognitive-behavioral model proposed by Cash (2011, p. 39), and assumed in this paper, considers most contemporary research on physical appearance distinguished in two categories: (a) body image evaluation, which "refers to individuals' satisfaction or dissatisfaction with their bodies and their evaluative beliefs about it" and (b) body image investment which "refers to the cognitive, behavioral, and emotional importance of the body for self-evaluation."

First of all, considering the complexity of body image construct, the main issue is to define which particular dimension of body image will be assessed. After that, it is possible to select the suitable tool. Experts have drawn several recommendations about methodological concerns (Gardner, 1998; Thompson, 2004; Gardner \& Brown, 2010; Cash, 2011).

Regarding women's body image discussed here, focusing on subjective and attitudinal dimensions of body image construct, Thompson (2012) presents four types of measures to capture them, which are: (a) a global or site-specific body image satisfaction/dissatisfaction, (b) an affective component, (c) a behavioral construct, and (d) a cognitive aspect.

The most common way to measure global subjective dimension of body image, as body satisfaction or dissatisfaction is the figural rating scales (FRS). The FRS consists of a drawings or silhouettes of the human body ranging from very underweight to overweight or obese figures. Individuals are instructed to choose the figure that best represents their currently actual body, and then they are instructed to choose the figure that best represents their desired body size or their ideal physical appearance (Thompson, 2012; Scagliusi et al., 2006; Kakeshita, Silva, Zanata, \& Almeida, 2009). Body image dissatisfaction is measured by the difference between the chosen figures. There are also some questionnaires and Likert-type response scales, for measuring site-specific body satisfaction/ dissatisfaction, as the Body Shape Questionnaire (BSQ), which was already adapted into Portuguese and is widely used in Brazilian research (Scagliusi et al., 2006, Di Pietro \& Silveira, 2009; Hass, Garcia, \& Bertoletti, 2012).

The affective measures of body image assess feelings and emotions about people's own body, which may be influenced by the context. Body image dissatisfaction may be associated with anxiety, shame and distress because of weight status, muscle tone or a specific environmental situation or context as in some competitive sports cited above. Cognitive measures refer to beliefs, thoughts, interpretations and attributions about one's appearance or appearance ideals, and the level of importance they has in a person's life. Finally, behavioral measures of body image refer to behavioral manifestations of body image functioning as avoidance of mirrors, weighing and body checking (Thompson, Burke, \& Krawczyk, 2012; Menzel, Krawczyk, \& Thompson, 2011).

The question that arises then is: "looking good" for whom? A woman who matches all the characteristics of current beauty/attractiveness may feel bad about her look in case she has any disturbance in her body image; while a less attractive one might be quite satisfied with her appearance. Thus, the concept of "looking good" is extremely related to peoples' feelings, beliefs and perceptions about their bodies, and must be interpreted taking into account all the dimensions/components about the construct of body image.

\section{Brazilian women and their bodies}

"Body cult is rooted in Brazilian culture" endorsed Finger (2003, p. 1560), because "a sun-soaked tropical country where people walk around scantily clad for most of the year is fertile ground for vanity." "Traditional bodily proportions are being reshaped... In the feverish of an ideal body, many Brazilians have become obsessed by beauty."

Goldemberg (2010) discussed changes on Brazilians women's ideal of body and beauty, the "boom" in the beauty industry in Brazil citing the American anthropologist Alexander Edmonds's (2002) work. They announced data about employment in beauty sector, plastic surgery procedures to sculpt ideal body, and an aesthetic standard called "good shape/fitness" or "being in shape," and they argued about Brazilian fashion models whose main capital is a lean, young and beautiful body, that means success and prestige. 
Additionally, Goldemberg (2010, p. 232) stated that no wonder "fat is the major enemy in a culture adept at judging, classifying and ranking people based on physical appearance. Not being fat is not enough, but one must also cultivate a firm, toned, and muscular body. Fat and flaccidity are considered a tangible symbol of lack of discipline, laziness, messiness, almost a moral shortcoming reflected on the unwillingness to work on oneself." Nevertheless, the obsession with perfect body shape and great dissatisfaction with some physical characteristic may be sign to body image disturbance, and even a disease as body dysmorphic disorder (Phillips, 2011).

\section{Research in Brazil}

Historically, international studies on body image have focused on eating pathology and weight/shape concerns among young women (Cash \& Smolak, 2011). Interestingly, contrarily to other Western societies, in Brazil the core of investigations started within patients in several medical conditions other than eating disorders (e. g. Souza et al., 1986; Fernandez \& Loureiro, 1990; Mello \& Marques, 1995; Rubio, 1999). Another curious fact related to researches on body image in the country is that the interest on the theme is quite recent.

A search of a prominent database, Scopus, allows us to visualize what Brazilians' researchers have been investigating about the theme among adults (Table 1). Clearly, the amount of studies within feminine sex is more than twice higher compared to the opposite sex. Additionally, a recent survey conducted by our group on the actual state of knowledge about the issue in Brazil (Laus, Kakeshita, Fortes, Braga, Ferreira, \& Almeida, 2013) detected 31 instruments developed/adapted to adults, which are capable of assessing different dimensions of the construct in men and women. Of these, 10 are exclusively to females and 12 can be applied in both sexes. Notably, a great number of measures explores questions related to body (dis)satisfaction $(n=7)$, fact that reflects the current scenario of studies in the country.

Data from these researches highlight the low prevalence of satisfaction among our women-more than $70 \%$ of them reported to be dissatisfied with some aspect of their bodies (Bosi, Luiz, Uchimura, \& Oliveira, 2008; Coqueiro, Petrosky, Pelegrini, \& Barbosa, 2008; Alvarenga, Philippi, Lourenço, Sato, \& Scagliusi, 2010; Quadros et al., 2010). Frequently, the dominant complaint is related to weight and, undeniably, the most common desire is to be thinner, even when they are underweight or eutrophic (Kakeshita \& Almeida, 2006; 2008).

Nearly all authors agree with Thomas Cash (2011) when he proposes that body dissatisfaction derives from the discrepancy between one's self-perceived body and the personally valued body ideal. Thus, as already said elsewhere, if we consider that the female's ideal body is extremely thin and that this ideal is unreachable by almost all women, dissatisfaction is a likely consequence. Moreover, these findings are preoccupying if it were taken into account
Table 1. Number of paper published and indexed in Scopus.

\begin{tabular}{lc}
\hline \multicolumn{1}{c}{ Key-words } & $\begin{array}{c}\text { Number of } \\
\text { publications }\end{array}$ \\
\hline "Body image" AND Brazil AND women & 43 \\
"Body image" AND Brazil AND men & 15 \\
"Body image" AND Brazil AND female & 134 \\
"Body image" AND Brazil AND male & 86 \\
"Body dissatisfaction" AND Brazil AND women & 5 \\
"Body dissatisfaction" AND Brazil AND men & 1 \\
"Body dissatisfaction" AND Brazil AND female & 22 \\
"Body dissatisfaction" AND Brazil AND male & 12 \\
\hline
\end{tabular}

that this disturbance is strictly related to several harmful behaviors (e.g. dieting practices, skipping meals, laxative and diuretics use, and exercising excessively).

Indeed, there is a plethora of researches that have demonstrated the high frequency of these behaviors among Brazilian women. For example, data from the study of Costa and Vasconcelos (2010), who interviewed 220 women, demonstrated that $14.6 \%$ of them abstained from eating frequently, very frequently or always; and this practice was prevalent among women who were dissatisfied with their bodies (96.8\%). Ribeiro and Carvalho (2009) observed that $50 \%$ of women from their sample have already done some kind of dieting to weight loss; and of these, $86 \%$ ended up consuming some medication to reduce weight, concomitantly. Moreover, $27 \%$ of the interviewed took these substances without trying any other method of dieting before. In $92 \%$ of these cases, the ingestion of medication was not related to any pathology, which leads the authors to conclude that its use was linked to appearance related concerns. Exercising is another common practice adopted by women when trying to control weight. According to Zamai and Costa (2008) and Fermino, Pezzini, and Reis (2010), the main reasons for starting/maintaining a physical activity program among females are aesthetic/appearance concerns, harmony of the body and weight control.

A question that remains unanswered is how exactly exercising acts moderating body image dissatisfaction. While some authors consider that dissatisfied women look for physical activities to conform to popular ideals of beauty (Allender, Cowburn, \& Foster, 2006) and to change their weight or shape (Slater \& Tiggemann, 2011); others presume dissatisfaction as a consequence of the exercise, by affirming that many features that may elevate body dissatisfaction in women are contained in fitness center environment (e.g. mirrors, images of ideal female bodies, wearing of tight and revealing exercise clothing) (Slater \& Tiggemann, 2011); and also that perhaps dissatisfaction is experienced by young women as result from a disappointment by not achieving the desired body (Davis \& Cowles, 1991). 


\section{Modern health dichotomy}

Dichotomy [from Greek dichotomia "a cutting in half," from dicha "in two, asunder" (related to dis "twice") + temnein "to cut"], according to on line MacMillan Dictionary (2013) and Houaiss (2009) dictionary, means a difference between two completely opposite ideas or things, and it is used to mean: (a) In the classification of mental disorders in psychiatry or clinical psychology, dichotomous classification or categorization refers to the use of cut-offs intended to separate disorder from non-disorder at some level of abnormality, severity or disability. (b) In the anthropological field of theology and in philosophy, dichotomy is the belief that humans consist of a soul and a body. The mind-body problem in philosophy examines the relationship between mind and matter, and in particular the relationship between consciousness and the brain. The problem was famously addressed by René Descartes in the $17^{\text {th }}$ century, resulting in Cartesian dualism. Dualism maintains a rigid distinction between the realms of mind and matter. Monism maintains that there is only one kind of stuff, and that mind and matter are both aspects of it.

Living well or looking good may be considered the most modern health dichotomy. They are not the same thing, but they are not excluding, neither being healthy nor looking healthy.

Regarding living well, Brazil is characterized by inequalities of social, educational and economic status, income, male and female's role and opportunities, and health attendance and practice. As a developing and emergent country, there is still considerable prevalence of undernourishment and illiteracy as opposed of growing rates of obesity and high graduated people.

Concerning looking good, on one hand, there are the unattainable model's body, the standard body that must be lean, sculpted and with toned muscle, and on the other hand there are the generalized body dissatisfaction and the marketing of "unhealthy" foods, with high levels of sugar and fat.

The issues exposed so far, especially regarding women's body, seem to be cross-cultural and not culturally limited; neither limited to a specific social economic status nor a special life stage. The field's literature is huge and full of formal, informal and scientific material all over the world.

Thus, in contemporary days, it is almost a utopia achieving a healthy and functional body and looking good, which would permit living well, with quality of life. This is the main health dichotomy and the greatest health challenge.

This paper is a brief and limited overview on health and body image and there is still too much to be done on research. Thus, it is an effort to contribute more to people's health than people's appearance, related more to moral and ethical behaviors than to body cult and consumption behaviors in all senses.

\section{References}

Allender, S., Cowburn, G., \& Foster, C. (2006). Understanding participation in sport and physical activity among children and adults: a review of qualitative studies. Health Education Research, 21, 826-835.

Alvarenga, M. S.,P hilippi, S. T., Lourenço, B. H., Sato, P. M., \& Scagliusi F. B. (2010). Insatisfação com a imagem corporal em universitárias brasileiras. Jornal Brasileiro de Psiquiatria, 59 , 44-51.

Bosi, M. L. M., Luiz, R. R., Uchimura, K. Y., \& Oliveira, F. P. (2008). Comportamento alimentar e imagem corporal entre estudantes de educação física. Jornal Brasileiro de Psiquiatria, 57, 28-33.

BRASIL, Ministério da Saúde (2004). Análise da Estratégia global para alimentação Saudável, Atividade Física e Saúde. Portaria ${ }^{\circ} 596$ de 8 de abril de 2004.

Cash, T. F. (2011). Cognitive-behavioral perspectives on body image. In: T. F. Cash, \& L. Smolak (Eds.), Body image: a handbook of science, practice, and prevention (pp. 39-47). New York: The Guilford.

Cash, T. F. (Ed) (2012). Encyclopedia of Body Image and Human Appearance. Waltham: Academic Press.

Cash, T. F. \& Smolak, L. (2011). Understanding Body Image: Historical and contemporary Perspectives. In: T. F. Cash, \& L. Smolak (Eds.), Body image: a handbook of science, practice, and prevention (pp. 3-11). New York: The Guilford Press.

Coqueiro, R. S., Petroski, E. L., Pelegrini, A., \& Barbosa, A. R. (2008). Insatisfação com a imagem corporal: avaliação comparativa da associação com o estado nutricional em universitários. Revista de Psiquiatria RS, 30, 31-38.

Costa, L. C. F., \& Vasconcelos, F. A. G. (2010). Influence of socioeconomic, behavioral and nutritional factors in body image dissatisfaction among female university students in Florianopolis, SC. Revista Brasileira de Epidemiologia, 13, 112.

Davis, C., \& Cowles, M. (1991). Body image and exercise: a study of relationships and comparisons between physically active men and women. Sex Roles, 25, 33-44.

Dichotomy. (2013). In Macmillan dictionary on line. Retrieved from http://www.macmillandictionary.com/dictionary/ american/dichotomy.

Di Pietro, M., \& Silveira, D. X. (2009). Internal validity, dimensionality and performance of the Body Shape Questionnaire in a group of Brazilian college students. Revista Brasileira de Psiquiatria, 31, 21-24.

Edmonds, A. (2002). No universo da beleza: notas de campo sobre cirurgia plástica no Rio de Janeiro. In: A. Edmonds, $N u$ \& Vestido. Rio de Janeiro: Record.

Fermino, R. C., Pezzini, M. R., \& Reis, R. S. (2010). Motivos para prática de atividade física e imagem corporal em frequentadores de academia. Revista Brasileira de Medicina do Esporte, 16, 18-23.

Fernandez, J. M., \& Loureiro, S. R. (1990). Representação da imagem corporal em pacientes portadores de alterações vestibulares - Doença de Meniere. Psicologia: Teoria e Pesquisa, 6, 295-307.

Finger, C. (2003). Brazilian beauty: Brazil's cosmetic surgery industry is thriving, but why is beauty so important? The Lancet, 362, 1560.

Gardner, R. M. (1996). Methodological issues in assessment of the perceptual component of body image disturbance. British Journal of Psychology, 87, 327-337. 
Gardner, R. M. \& Brown, D. L. (2010). Body image assessment: A review of figural drawing scales. Personality and Individual Differences, 48, 107-111.

Gardner, R. M., Friedman, B. N. \& Jackson, N. A. (1998). Methodological concerns when using silhouettes to measure body image. Perceptual and Motor Skills, 86, 387-395.

Goldenberg, M. (2010). The body as capital: Understanding Brazilian culture. Vibrant, 7, 220-238.

Grogan, S. (2008). Body Image: Understanding Body Dissatisfaction in Men, Women, and Children. London, UK and New York, USA: Routledge, Taylor \& Francis Group.

Hass, A. N.; Garcia, A. C. D. \& Bertoletti, J. (2012). Body image of Professional ballet dancers. Revista Brasileira de Medicina do Esporte, 16, 182-185.

Kakeshita, I. S., \& Almeida, S. S. (2006). Relationship between body mass index and self-perception among university students. Revista de Saúde Pública, 40, 497-504.

Kakeshita, I. S., \& Almeida, S. S. (2008). Estudo da relação entre o índice de massa corporal e o comportamento alimentar de adultos. Nutrire: Revista da Sociedade Brasileira de Alimentação e Nutrição, 33, 21-30.

Kakeshita, I. S., Silva, A. I. P., Zanata, D. P. \& Almeida, S. S. (2009). A Figure Rating Scales for Brazilian Adults and Children: Development and Test-Retest Reliability. Psicologia: Teoria e Pesquisa, 25, 263-270.

Laus, M. F.; Zancul, M. S.; Martins, T. M.; Kakeshita, I. S.; Almeida, S. S. (2006). Percepção da imagem corporal e estado nutricional em estudantes de nutrição. Alimentos e Nutrição, $17,85-89$.

Laus, M. F. (2013). Influêcia do padrão de beleza veiculado pela mídia na satisfação corporal e escolha alimentar de adultos. Doctoral dissertation, Departamento de Psicologia, Faculdade de Filosofia, Ciências e Letras de Ribeirão Preto, Universidade de São Paulo, Ribeirão Preto.

Laus, M. F.; Kakeshita, I. S.; Fortes, L. S.; Costa, T. M. B.; Ferreira, M. E. C. \& Almeida, S. S. (2013). Body image research in Brazil: recent advances in the state of knowledge and methodological issues [Manuscript on preparation].

LePage, M.L. \& Crowther, J.H. (2010). The effects of exercise on body satisfaction and affect. Body Image, 7, 124-130.

McKinley, N.M. (2011). Feminist Perspectives on Body Image. In: T. F. Cash, \& L. Smolak (Eds.), Body image: a handbook of science, practice, and prevention (pp. 3-11). New York: The Guilford Press.

Mello, M., \& Marques, A. P. (1995). A imagem corporal representada pelos fibromálgicos: um estudo preliminar. Revista de Fisioterapia da Universidade de São Paulo, 2, 87-93.

Menzel, J. E.; Krawczyk, R. \& Thompson, J. K. (2011). Attitudinal Assessment of Body Image for Adolescents and Adults. In: T. F. Cash, \& L. Smolak (Eds.), Body image: a handbook of science, practice, and prevention (pp. 3-11). New York: The Guilford Press.

Petrie, TA \& Greenleaf, G. (2012). Body Image and Sports/ Athletics. In: T. F. Cash, (Ed), Encyclopedia of Body Image and Human Appearance (vol I, pp. 409-422). Waltham: Academic Press.

Phillips, K.A.(2011). Body image and Body Dysmorphic Disorder. In: T. F. Cash, \& L. Smolak (Eds.), Body image: a handbook of science, practice, and prevention (pp. 3-11). New York: The Guilford Press.

Quadros, T. M. B., Gordia, A. P., Martins, C. R., Silva, D. A. S., Ferrari, E. P., \& Petroski, E. L. (2010). Imagem corporal em universitários: associação com estado nutricional e sexo. Mo- triz, 16, 78-85.

Ribeiro, S., \& Carvalho, R. J. M. (2009). Uso de medicamentos para redução de peso corporal. Seminário Científico de Nutrição, 1 .

Rubio, K. (1999). Entre o discurso e a imagem corporal: um estudo sobre o imaginário da hanseníase. Psicologia Revista, 9, 7593.

Scagliusi, F. B.; Alvarenga, M.; Polacow, V. O.; Cordas, T. A.; Queiroz, G. K. O.; Coelho, D.; Philippi, S. T.; Lancha A. H., Jr. (2006). Concurrent and discriminant validity of the Stunkard's figure rating scale adapted into Portuguese. Appetite, 47, 77-82.

Schilder, P. (1950, 1999). A imagem do corpo: as energias construtivas da psique. $3^{\text {a }}$ ed. São Paulo: Martins Fontes.

Sentilles, RM \& Callahan, K. (2012). Beauty over the Centuries Female. In: T. F. Cash (Ed), Encyclopedia of Body Image and Human Appearance. (vol I, pp. 139-155). Waltham: Academic Press.

Slater, A., \& Tiggemann, M. (2011). Gender differences in adolescent sport participation, teasing, self-objectification and body image concerns. Journal of Adolescence, 34(3), 455-463. doi: 10.1016/j.adole scence.2010.06.007

Souza, M. C., Cerezetti, C. R. N., Sousa Júnior, A. H. S., Nahas, P., Habr Gama, A., Neder, M., Pinotti, H. W. (1986). Mudanças na imagem corporal e alterações psicológicas em pacientes colostomizados e ileostomizados. Revista do Colégio Brasileiro de Cirurgiões, 13, 159-163.

Thompson, J. K. (2004). The (mis)measurement of body image: ten strategies to improve assessment for applied and research purposes. Body Image, 1, 7-14.

Thompson, J. K., Burke, N. L. \& Krawczyk. (2012). Measurement of Body Image in Adolescence and Adulthood. In: T. F. Cash (Ed), Encyclopedia of Body Image and Human Appearance (vol II, pp. 1175-1185). Waltham: Academic Press.

Thompson JK, Heinberg LJ, Altabe M, Tantleff-Dunn S. (1999). Exacting beauty: theory, assessment, and treatment of body image disturbance. Washington (DC): American Psychological Association.

U.S. Department of Health and Human Services (HHS). Office on women's Health. (2013). A Lifetime of Good Health: Your Guide to Staying Healthy. Retrieved from http://womenshealth.gov/ publications/our-publications/lifetime-good-health/ LifetimeGoodHealth-English.pdf.

Van Den Berg, P.; Thompson, JK; Obremski-Brandon, K. \& Coovert, M., (2002). The Tripartite influence model of body image and eating disturbance - a covariance structure modeling investigation testing the mediational role of appearance comparison. Journal of Psychosomatic Research, 53, 100720.

Vieira,J. L.; Amorim, H. Z.; Vieira, L.F.; Amorim, A. C. \& Rocha, P. G. M. (2009). Eating disorders and body image distortion in the rhythmic gymnastics competitive context. Revista Brasileira de Medicina do Esporte, 15, 410-414.

WHO (2003). MDG 3: Promote gender equality and empower women. Retrieved from http://www.who.int/topics/ millennium_development_goals/gender/en/index.html.

WHO (2009). Milestones in Health Promotion: Statements from Global Conferences. Retrieved from http://www.who.int/ healthpromotionMilestones_Health_Promotion_05022010.pdf.

Zamai, C. A., \& Costa, M. S. (2008). Prática de exercícios físicos entre mulheres frequentadoras de academias na cidade de Campinas (SP). Movimento \& Percepção, 9, 266-286. 


\section{Authors' note}

Idalina Shiraishi Kakeshita, Maria Fernanda Laus, Sebastião Sousa Almeida are affiliated with the Laboratory of Nutrition and Behavior, Department of Psychology, Faculty of Philosophy, Sciences, and Letters of Ribeirão Preto, University of São Paulo.

\section{Correspondence}

Dr. Sebastião de Sousa Almeida.

Faculty of Philosophy, Sciences, and Letters of Ribeirão Preto, University of Sao Paulo

Av. Bandeirantes, 3900, Monte Alegre, 14040901

Ribeirão Preto, SP, Brazil.

Tel.: +551636023663.

E-mail address: sebasalm@usp.br

\section{Acknowledgements}

Editorial board of Brazilian Journal Motriz and Organizing Committee of the VIII International Congress of Physical Activity and Human Movement Sciences (VIII CIEFMH - XIV SPEF) for the invitation.

FAPESP for the financial support of a post-doctoral position to the first author.

This study was presented as part of an invited lecture at the $8^{\text {th }}$ International Congress of Physical Education and Human Movement and $14^{\text {th }}$ Symposium Paulista Physical Education.

Declaration of Conflicting Interests: The authors declared no conflicts of interest with respect to the research, authorship, and/ or publication of this article.

Manuscript received on March 30, 2013

Manuscript accepted on May 10, 2013 